\title{
Tubal and cervical cultures in acute salpingitis with special reference to Mycoplasma hominis and T-strain mycoplasmas
}

\author{
P. -A. MÅRDH AND L. WESTRÖM \\ Institute of Medical Microbiology, University of Lund, \\ and Department of Obstetrics and Gynaecology, University Hospital, Lund, Sweden
}

Most workers agree that acute salpingitis is generally caused by an infection ascending from the lower genital tract. Cultures from the cervix, however, give in most cases no conclusive evidence as to the cause of the infection in the fallopian tubes (Heynemann, 1953; Pinkerton, 1963). The difficulty in obtaining specimens from the uterine tubes, especially in the acute stage of the disease, has been a major obstacle in aetiological studies. When bacterial cultures have been made from material obtained from the fallopian tubes or aspirates from the pouch of Douglas, sampling has generally been made when the acute symptoms have subsided or in patients in whom complications have necessitated laparotomy. In such cases, bacterial cultures from the tubes have often yielded no growth of bacteria.

With the introduction of laparoscopy, a direct and objective means of diagnosing salpingitis has been obtained (Sjövall, 1965). Laparoscopy has also offered the possibility of obtaining specimens for culture directly from the uterine tubes in the early acute stage of salpingitis.

The first isolation of Mycoplasma in man was made by Dienes and Edsall (1937) from a Bartholin's gland abscess. Much work has since been done on isolations of Mycoplasma in the female genital tract (Hayflick and Chanock, 1965). Most of these investigations have concerned the so-called classic genital strains of Mycoplasma. When isolated strains have been typed, they have nearly always been identified as Mycoplasma hominis type 1 , rarely as Mycoplasma fermentans. In contrast to the interest taken in classic genital strains, few reports have been published on T-strain Mycoplasma in the female genital tract (Ford and DuVernet, 1963; Shepard, Alexander, Lunceford, and Campbell, 1964; Csonka, Williams, and Corse, 1966; Archer, 1968). The T-strains, which differ in many characteristics from the classic genital strains (Shepard, 1967), include at least six serologically different types (Ford, 1967).
Women with genital infections often harbour classic Mycoplasma in the lower genital tract (Melén and Ödeblad, 1951; Freundt, 1953; KlienebergerNobel, 1960). On the other hand, classic strains of Mycoplasma were recovered in only 2 per cent. of healthy females in whom the vaginal flora was dominated by Döderlein's bacillus (Freundt, 1953).

Isolations of classic Mycoplasma from advanced inflammatory conditions of the adnexa, such as tuboovarian abscesses, have been reported in six instances (Dienes, Ropes, Smith, Madoff, and Bauer, 1948; Randall, Stein, and Ayres, 1950; Hirsch, 1952; Gotthardson and Melén, 1953 [two cases]; Stokes, 1955). Freundt (1953) isolated $M$. fermentans from a fallopian tube with signs of infection. Serological investigations have indicated a possible aetiological relationship of Mycoplasma to salpingitis (Melén and Gotthardson, 1955; Lemcke and Csonka, 1962).

The present study was undertaken to investigate the occurrence of classic Mycoplasma, T-strain Mycoplasma, bacteria, and Trichomonas vaginalis in the uterine tubes of laparoscopized patients with acute salpingitis. Cervical and urethral specimens were also obtained. Women with infections confined to the lower genital tract and healthy females were also investigated.

\section{Material}

SALPINGITIS PATIENTS (50 cases)

The patients in this group presented with a history and clinical signs suggestive of acute salpingitis. In all cases the diagnosis was confirmed by laparoscopy, which was performed immediately after admission and before any treatment had been initiated. The criteria for laparoscopic diagnosis of salpingitis were the same as those reported by Siövall (1965) and Jacobson (1964).

WOMEN WITH INFECTIONS CONFINED TO THE LOWER GENITAL TRACT * (50 cases)

As diagnostic criteria, at least two of the following signs had to be present: purulent or sanguino-purulent discharge from the cervical os, abnormal pain on bimanual

*Lower genital tract infection will henceforth be abbreviated as LGTI 
palpation of the cervix, reddened vaginal mucosa. On admission, acute salpingitis was suspected in 21 patients, but laparoscopy revealed normal fallopian tubes. In these patients, specimens were obtained from the tubes. In the remaining 29 women, specimens were obtained only from the lower genital tract. None of the women in the LGTI group had received treatment before sampling.

\section{NON-INFECTED CONTROLS (50 cases)}

None of the women in this group had any symptoms referable to infection in the genital tract. Examination revealed normal conditions with whitish creamy vaginal contents and normal mucus from the cervical os. 37 women had applied to the out-patients department for a routine health check-up or contraceptive advice. Included in the group were thirteen women without signs of LGTI, but who were laparoscopized because of acute abdominal pain. Laparoscopy revealed, in all instances, normal fallopian tubes. The explanation of the condition was intraabdominal ovulatory bleeding. From these thirteen patients, specimens were obtained from the tubes, and from the other 37 women, specimens were obtained only from the lower genital tract.

No selection was made of the patients in the salpingitis group. The women in the LGTI and non-infected control groups were so selected that their age and socio-economic background were comparable to those of the salpingitis patients. All the investigated women were non-pregnant. They were all sexually active.

The number of subjects investigated and the age distribution within the three groups are shown in Table I.

\section{Methods}

Specimens for isolation of classic Mycoplasma, T-strain Mycoplasma, and Neisseria gonorrhoeae were collected from the urethra, cervix, uterine tubes, and the pouch of Douglas. For the isolation of $N$. gonorrhoeae, samples were also collected from the rectum. Specimens for isolation of bacteria (other than $N$. gonorrhoeae) and of $T$. vaginalis were collected from the cervix, uterine tubes, and pouch of Douglas.

\section{SAMPLING AND LAPAROSCOPIC TECHNIQUES}

The cervical os and the urethral orifice were exposed by inserting a sterile speculum into the vagina. Specimens were collected by rotating sterile cotton-tipped swabs in the cervical canal and the urethra. For the isolation of $N$. gonorrhoeae, specimens were collected with cotton-tipped swabs treated with charcoal. Sampling was made before palpation or other diagnostic procedures were undertaken.

Laparoscopy was performed according to the method of Sjövall (1962). The abdominal wall was perforated with a cannula and the abdominal cavity was filled with carbon dioxide. The laparoscope was inserted in the midline just below the umbilicus, and one or two cannulae into the suprapubic region. The cannulae enabled the manipulation of the internal genital organs and the collection of specimens. Material from the fallopian tubes was aspirated into thin plastic catheters, which were inserted via the cannulae through the abdominal orifices of the fallopian tubes. If the orifices were closed by the inflammatory process, the tubes were punctured with needles under visual control and their contents aspirated directly into sterile syringes. Pus or exudate in the pouch of Douglas was collected separately.

The samples were immediately transferred to the transport media, and were dealt with in the laboratory within 2 hours.

\section{TRANSPORT MEDIA}

Specimens intended for isolation of classic Mycoplasma and T-strains were transported on a modified Stuart's medium (Gästrin, Kallings, and Marcetic, 1968), as well as on heart-infusion broth (Difco) with 10 per cent. horse serum. Specimens from the cervix were also inoculated directly on the PPLO medium described below (2). For isolation of bacteria, specimens were transported in haematin-agar test tubes and on the modified Stuart's medium. Specimens from the fallopian tubes and the pouch of Douglas were also inoculated onto thioglycollate broth.

\section{ISOLATION OF CLASSIC MYCOPLASMA} Media

(1) Heart-infusion broth or agar (Difco) $100 \mathrm{ml}$., horse serum $20 \mathrm{ml}$., yeast extract (baker's yeast 25 per cent.) $10 \mathrm{ml}$. Sodium penicillin $1,500 \mathrm{i} . \mathrm{u} . / \mathrm{ml}$. Thallium acetate in a final concentration of 1:2,000.

(2) PPLO broth or agar (Difco) $90 \mathrm{ml}$, horse serum 20 ml., yeast extract (baker's yeast 25 per cent.) $10 \mathrm{ml}$. Sodium penicillin 1,500 i.u. $/ \mathrm{ml}$. Thallium acetate in a final concentration of $1: 2,000$.

From the transport media, inoculations were made both into fluid and onto solid media. The fluid media were incubated at $37^{\circ} \mathrm{C}$. for 3 days after which inoculations were made onto solid medium of the same composition. The plates were incubated at $37^{\circ} \mathrm{C}$. in an atmosphere of 90 per cent. nitrogen and 10 per cent. carbon dioxide and were read after 4 days under a stereomicroscope. If no growth was observed, the plates were incubated and reexamined twice during the following week.

Isolated strains were identified by growth-inhibition tests (Clyde, 1964).

TABLE I Age distribution in the salpingitis, LGTI, and non-infected control groups

\begin{tabular}{|c|c|c|c|c|c|c|}
\hline \multirow[b]{2}{*}{ Groups } & \multirow{2}{*}{$\begin{array}{l}\text { No. of } \\
\text { cases }\end{array}$} & \multicolumn{5}{|c|}{ Age group (yrs) } \\
\hline & & $\overline{16-20}$ & $21-25$ & $26-30$ & $31-35$ & $>35$ \\
\hline $\begin{array}{l}\text { Salpingitis } \\
\text { LGTI } \\
\text { Non-infected controls }\end{array}$ & $\begin{array}{l}50 \\
50 \\
50\end{array}$ & $\begin{array}{l}17 \\
15 \\
18\end{array}$ & $\begin{array}{l}24 \\
18 \\
20\end{array}$ & $\begin{array}{l}5 \\
8 \\
6\end{array}$ & $\begin{array}{l}3 \\
4 \\
4\end{array}$ & $\begin{array}{l}1 \\
5 \\
2\end{array}$ \\
\hline
\end{tabular}


ISOLATION OF T-STRAINS

Medium (Shepard)

Trypticase soy broth (Baltimore Biological Laboratories) 3 per cent., horse serum 20 per cent., nucleotide solution (calf thymus, Sigma) 0.002 per cent. Sodium penicillin 1,500 i.u./ml. For solid medium, Ionagar No. 2 (Oxoid) $1 \cdot 13$ per cent. was added. The final $\mathrm{pH}$ of the medium was adjusted to 6 with $1 \mathrm{~N} \mathrm{HCl}$.

From the transport media, inoculations were made into fluid and onto solid media. The fluid medium was incubated at $37^{\circ} \mathrm{C}$. for 18 hours, after which inoculations were made onto solid medium. The plates were incubated as described for classic Mycoplasma and read under a microscope after 2,3 , and 7 days. The last reading was made in order to check the possible growth of classic Mycoplasma.

The isolated strains were tested for their ability to utilize urea (Shepard and Lunceford, 1967).

\section{ISOLATION OF BACTERIA}

\section{Media}

(1) Blood-agar plates. Blood Agar Base No. 2 (Oxoid) with 4 per cent. defibrinated horse blood.

(2) Haematin-agar plates. Blood Agar Base No. 2 (Oxoid) with 7 per cent. defibrinated horse blood heated at $80^{\circ} \mathrm{C}$. for 10 minutes.

(3) Haematin-agar plates (Reyn, 1965) with 25 i.u. $/ \mathrm{ml}$. polymyxine.

Inoculations from the transport media were made onto blood-agar plates, which were incubated aerobically, as well as in anaerobic jars in an atmosphere of hydrogen. Inoculations were also made on haematin-agar plates (2), which were incubated in 10 per cent. carbon dioxide. Specimens from the fallopian tubes and the pouch of Douglas were also inoculated on trypticase soy broth and thioglycollate broth.

For the isolation of $N$. gonorrhoeae, inoculations were made from the modified Stuart's medium onto haematinagar plates (3), which were incubated in 10 per cent. carbon dioxide.

\section{IDENTIFICATION OF $T$. vaginalis}

\section{Medium}

Oxoid Trichomonas medium No. 2 with 8 per cent. horse serum. Penicillin 1,000 i.u./ml. Streptomycin $500 \mathrm{mg} . / \mathrm{ml}$.

Contents from the posterior vaginal fornix were examined microscopically as wet smears directly after the collection. Material from the tubes and posterior vaginal fornix were cultured for $T$. vaginalis.
The specimens were inoculated into the medium directly after sampling. Incubation was at $37^{\circ} \mathrm{C}$. Microscopic examination of samples from the broths were made at intervals for up to one week.

\section{Results}

\section{CLASSIC MYCOPLASMA}

The incidence of $M$. hominis and $M$. fermentans is shown in Table II.

$M$. hominis Type 1 was isolated from the cervix in 54 per cent. of the patients with clinical signs of infection in the lower genital tract. In the noninfected controls, $M$. hominis was recovered from the cervix in two out of fifty women examined (4 per cent.). In one of these two women, cervical cultures also yielded an abundant growth of Candida albicans and in the other $T$. vaginalis was cultured from the cervix.

In the salpingitis group, $M$. hominis was isolated from the cervix in 62 per cent. and in the LGTI group in 46 per cent. This difference was not significant $\left(\chi^{2}=2.577 ; P>0.1\right)$. On the other hand, there was a highly significant difference in the isolation rates of $M$. hominis in the cervix between noninfected controls and patients with clinical signs of infection, i.e. salpingitis and LGTI patients $\left(\chi^{2}=\right.$ 35.756; $\mathrm{P}<0.001)$.

A comparison between the results of cultures from the urethra and the cervix showed that $M$. hominis, if isolated, was rarely recovered exclusively from the urethra or the cervix. Thus, $M$. hominis was isolated only from the urethra in one case and only from the cervix in five cases, while cultures yielded growth from both sites in fifty cases.

The incidence of $M$. hominis in salpingitis and LGTI patients with and without gonorrhoea was about the same $\left(\chi^{2}=0.850 ; P>0.3\right.$; Table III). Moreover, no difference was found in the incidence of $M$. hominis in women with and without trichomonal infestations $\left(\chi^{2}=0.169 ; P>0.5\right.$; Table III).

From the fallopian tubes, $M$. hominis was isolated in pure culture in four of the salpingitis cases, and in two of these $M$. hominis was also recovered from exudate in the pouch of Douglas. Thus, $M$. hominis was isolated from the uterine tubes in 12.9 per cent.

TABLE II Incidence of M. hominis, $M$. fermentans, and T-strains in the lower genital tract and fallopian tubes

\begin{tabular}{|c|c|c|c|c|c|c|c|c|}
\hline \multirow[b]{2}{*}{ Groups } & \multicolumn{4}{|c|}{ Lower genital tract } & \multicolumn{4}{|c|}{ Fallopian tubes } \\
\hline & $\begin{array}{l}\text { No. of } \\
\text { cases }\end{array}$ & $\begin{array}{l}\text { M. } \\
\text { hominis }\end{array}$ & $\begin{array}{l}\text { M. } \\
\text { fermentans }\end{array}$ & $T$-strain & $\begin{array}{l}\text { No. of } \\
\text { cases }\end{array}$ & $\begin{array}{l}\text { M. } \\
\text { hominis }\end{array}$ & $\begin{array}{l}\text { M. } \\
\text { fermentans }\end{array}$ & $T$-strain \\
\hline $\begin{array}{l}\text { Salpingitis } \\
\text { LGTI } \\
\text { Non-infected controls }\end{array}$ & $\begin{array}{l}50 \\
50 \\
50\end{array}$ & $\begin{array}{l}31 \\
23 \\
2\end{array}$ & $\frac{1}{-}$ & $\begin{array}{l}28 \\
22 \\
22\end{array}$ & $\begin{array}{l}50 \\
21 \\
13\end{array}$ & $\frac{4}{-}$ & $\overline{-}$ & - \\
\hline
\end{tabular}


TABLE III Incidence of $\mathrm{M}$. hominis, T-strains, and $\mathbf{T}$. vaginalis in the lower genital tract of salpingitis patients with and without gonorrhoea

\begin{tabular}{|c|c|c|c|c|c|c|c|}
\hline \multirow{3}{*}{$\begin{array}{l}\text { N. } \\
\text { gonor- } \\
\text { rhoeae }\end{array}$} & \multirow{3}{*}{$\begin{array}{l}\text { No. of } \\
\text { cases }\end{array}$} & \multicolumn{6}{|c|}{ Organism isolated } \\
\hline & & \multicolumn{2}{|c|}{ M. hominis } & \multicolumn{2}{|c|}{$T$-strains } & \multicolumn{2}{|c|}{$T$. vaginalis } \\
\hline & & No. & $\begin{array}{l}\text { Per } \\
\text { cent. }\end{array}$ & No. & $\begin{array}{l}\text { Per } \\
\text { cent. }\end{array}$ & No. & $\begin{array}{l}\text { Per } \\
\text { cent. }\end{array}$ \\
\hline \multirow{2}{*}{$\begin{array}{l}\text { Isolated } \\
\text { Not } \\
\text { isolated }\end{array}$} & 17 & 12 & $70 \cdot 6$ & 9 & 52.9 & 6 & $35 \cdot 3$ \\
\hline & 33 & 19 & $57 \cdot 6$ & 19 & $57 \cdot 6$ & 9 & $27 \cdot 3$ \\
\hline Total & 50 & 31 & $62 \cdot 0$ & 28 & $56 \cdot 0$ & 15 & $30 \cdot 0$ \\
\hline
\end{tabular}

of the salpingitis patients who harboured $M$. hominis in the cervix and in 8 per cent. of all salpingitis cases. None of the patients from whom $M$. hominis was isolated from the tubes had gonorrhoea.

$M$. hominis was not isolated from the tubes or pouch of Douglas in any of the 34 laparoscopized women in the LGTI and non-infected control groups.

In only one of the 150 individuals examined could the isolated strain of Mycoplasma be identified as M.fermentans.

\section{T-STRAIN MYCOPLASMA}

The results of the cultures for the $T$-strains are shown in Table II. T-strains were isolated from the lower genital tract in 56 per cent. of the salpingitis patients and in 44 per cent. of the LGTI patients. In all patients with genital infections, $T$-strains were recovered in 50 per cent. The corresponding figure for the non-infected controls was 44 per cent. There was no significant difference in the occurrence of $T$-strains in the lower genital tract between the salpingitis patients, the LGTI patients, and the noninfected control subjects $\left(\chi^{2}=1.923 ;\right.$ d.f. $\left.=2 ; P>0.3\right)$.

As with $M$. hominis, there was no difference in the occurrence of $\mathrm{T}$-strains in gonorrhoeal and nongonorrhoeal cases (Table III), nor in patients with and without trichomonal infestation.

In two of the salpingitis cases, $T$-strains were isolated from the fallopian tubes. In one of these patients the T-strains were isolated in pure culture, while in the other the tubal contents also yielded growth of Haemophilus influenzae. In both these cases $T$-strains were also recovered from the cervix. Neither of the patients had gonorrhoea. T-strains were not cultured from exudate or pus from the pouch of Douglas.

In the 34 cases of women with normal fallopian tubes at laparoscopy, $\mathrm{T}$-strains were not isolated from the tubes or pouch of Douglas in any instance.
SIMULTANEOUS OCCURRENCE OF $M$. hominis AND T-STRAINS

Both $M$. hominis and T-strains were demonstrated in 28 of the hundred women with genital infections, $\mathrm{T}$-strains only were isolated from 22 , and $M$. hominis only from 27 women.

\section{BACTERIA}

$N$. gonorrhoeae Gonococci were cultured from the lower genital tract in 34 per cent. of the patients in the salpingitis group (Table III). Gonococci were isolated in pure culture from the fallopian tubes from two women with salpingitis. Gonococci were recovered from both the tubes and the lower genital tract in 4 per cent. of the fifty salpingitis patients. None of the cultures from the pouch of Douglas yielded a growth of $N$. gonorrhoeae, and in no instance were gonococci isolated exclusively from the adnexa. Gonorrhoea was diagnosed in four of the LGTI cases ( 8 per cent.).

Bacteria apart from $N$. gonorrhoeae Specimens obtained from the fallopian tubes or the pouch of Douglas yielded growth in three of the salpingitis cases. In one case coliform rods (Enterobacter aerogenes) were isolated from the tubes and the pouch of Douglas. In the other two cases cultures from the tubes yielded a growth of coagulase-positive staphylococci and $H$. influenzae respectively. In none of these three cases did cervical cultures yield a growth of the bacterial species isolated from the tubes. No growth was obtained from specimens collected from the tubes or pouch of Douglas in the cases of 34 patients in whom laparoscopy revealed normal tubes.

The cultures from the cervix in the salpingitis and LGTI cases yielded a growth of variegated bacterial species. With the exception of $N$. gonorrhoeae, Escherichia coli, and Streptococcus faecalis, no single species was particularly frequent.

\section{Trichomonas vaginalis}

Trichomonal infestations were diagnosed in 30 and 22 per cent. of the patients in the salpingitis and LGTI groups respectively. The difference is not significant $\left(\chi^{2}=0.832 ; P>0.3\right)$. In the salpingitis group, $T$. vaginalis was demonstrated in the same percentage in patients with and without gonorrhoea (Table III). Cultures of specimens obtained from the posterior vaginal fornix revealed $T$. vaginalis in three cases in which microscopy of wet smears was negative. In none of the salpingitis cases, but one of the LGTI patients, $T$. vaginalis was demonstrated on culture of material from the tubes and pouch of Douglas. 
COMPARISON BETWEEN TRANSPORT MEDIA FOR MYCOPLASMA

The isolation rates of classic Mycoplasma from specimens transported on the modified Stuart's medium and the heart-infusion broth were equal. In some instances a heavy growth of bacteria or Candida albicans was obtained on cultures from the cervical specimens that had been transported on heartinfusion broth. In such instances a direct inoculation of cervical specimens into PPLO broth was superior to both transport media for the isolation of classic Mycoplasma.

The two transport media used for the isolation of T-strains gave approximately the same isolation frequency. However, the use of both transport media increased the total number of isolated strains by 15 per cent.

\section{Discussion}

The diagnosis of acute salpingitis has usually been based on indirect criteria, such as abdominal tenderness, palpable and painful mass in the pelvis, abnormal vaginal discharge, fever, and a raised erythrocyte sedimentation rate. However, the use of laparoscopy has shown that acute genital infections not involving the tubes may present the same symptoms and signs as acute salpingitis (Jacobson and Weström, 1969). In the present series, 71 patients presented a clinical picture suggestive of acute salpingitis. Laparoscopy confirmed the diagnosis in fifty cases (70.4 per cent.), while in the remaining 21 patients the tubes showed no sign of infection.

Apart from giving an objective means of diagnosing acute salpingitis, laparoscopy has offered excellent possibilities for obtaining samples directly from the fallopian tubes. In contrast to earlier sampling techniques, such as percutaneous puncture of tuboovarian abscesses, colpotomy, or laparotomy, sampling during laparoscopy has the advantage of being applicable to all suspected salpingitis cases, and may be used early in the course of the disease. A further advantage is that sampling is done under visual control. The earlier methods involved a high risk of secondary infection of the specimens during sampling. This risk may be avoided by the use of laparoscopy.

Most workers have reported a considerably higher isolation rate of classic Mycoplasma from the lower genital tract in women with genital infections than in healthy females. The frequency with which classic Mycoplasma has been recovered from healthy controls varies to a great extent. These variations may reflect differences in the choice of the control subjects. In this study the majority of the women investigated were unmarried business or professional women or university students. Those in the LGTI and non-infected control groups were selected to match those in the salpingitis group as to age, parity, marital status, socio-economic background, and sexual activity. In those women who were considered on clinical grounds to be gynaecologically healthy, $M$. hominis was isolated only occasionally, whereas more than half of the women with signs of genital infections harboured $M$. hominis in the lower genital tract.

It has been suggested that Mycoplasma infections are related to promiscuity. Classic Mycoplasma has been isolated particularly often from patients attending V.D. clinics. A high isolation rate has also been reported in women with gonorrhoea or trichomonal infestations (Hayflick and Chanock, 1965). In the present series there was no significant difference in the recovery rate of $M$. hominis in patients with gonorrhoea, trichomonal infestation, or 'non-specific' vaginitis $(65,73$, and 50 per cent. respectively; $\chi^{2}=0.946 ;$ d.f. $\left.=2 ; P>0.5\right)$.

In women with a predominance of acidophilic bacteria of Döderlein's type in their vaginal flora, $M$. hominis may seldom be isolated (Freundt, 1953). The same observation was made in the present series in which Papanicolau-stained vaginal smears showed a predominance of Döderlein's bacillus in only two out of 49 cases from which $M$. hominis was isolated.

$M$. fermentans was isolated from the lower genital tract in only one of our cases, whereas $M$. hominis was recovered from 56 women. This rarity of $M$. fermentans in the female genital tract accords with earlier reports (Hayflick and Chanock, 1965).

As mentioned, isolations of (presumably) $\mathrm{Myco-}$ plasma from advanced inflammatory conditions in the adnexa have been reported in six cases. In two of these, specimens were obtained by aspirating material from the pouch of Douglas per vaginam. Mycoplasma was isolated in pure culture from three of the patients, and treatment with penicillin had been given in four cases before sampling. In one case (Stokes, 1955), the isolated strain was later typed and identified as $M$. hominis. Freundt (1953) isolated $M$. fermentans in pure culture from a fallopian tube which histologically showed chronic inflammation with signs of acute exacerbation. His patient was not treated with antibiotics before sampling.

In this series, $M$. hominis was isolated in pure culture directly from the lumen of fallopian tubes with signs of acute inflammation. Sampling was performed early in the course of the disease and before the patients had been treated with antibiotics.

In none of the 34 patients in whom laparoscopy revealed normal uterine tubes, did tubal cultures yield a growth of $M$. hominis. Nor could $M$. hominis 
be isolated from the normal tubes of ten patients ${ }^{\star}$ subjected to hysterectomy. This agrees with a report by Freundt (1953), who did not recover classic Mycoplasma from normal uterine tubes removed at operation.

Under experimental conditions $M$. hominis has been shown to cause disease in man. Mufson, Ludwig, Purcell, Cate, Taylor-Robinson, and Chanock (1965) used $M$. hominis to produce exudative pharyngitis in man followed by a specific antibody response. Lemcke and Csonka (1962) found complement-fixing antibodies against $M$. hominis in 59 per cent. of women with salpingitis but in only 4 per cent. of a control group of blood donors. Melén and Gotthardson (1955) demonstrated a significant rise in the titre of complement-fixing antibodies against a pleuropneumonia-like organism in two cases of salpingitis.

Discussion on $\mathrm{T}$-strains in infectious conditions of the genito-urinary tract has mainly concerned nongonococcal urethritis (NGU) in the male (Black and Rasmussen, 1968). In females a high isolation rate of T-strains has been reported in the consorts of males with NGU (Shepard and others, 1964). In the present series no significant difference was demonstrated in the occurrence of $\mathrm{T}$-strains in healthy females and women with LGTI, which may indicate that $\mathrm{T}$-strains occur as commensals in the female genito-urinary tract. The role of T-strains in genital infections is at present difficult to evaluate, since differences may exist between various serological types. In the present study no attempts were made to separate the isolated strains serologically. The recovery of $\mathrm{T}$-strains from the fallopian tubes in salpingitis suggests that $\mathrm{T}$-strain Mycoplasma might be associated with inflammatory conditions of the adnexa.

$N$. gonorrhoeae may frequently be cultured from the lower genital tract in patients with salpingitis, and according to the results of such cultures the condition has usually been classified as gonorrhoeal or non-gonorrhoeal salpingitis. There has, however, been no unanimity as to the frequency with which $N$. gonorrhoeae causes the infection in the fallopian tubes themselves (Curtis, 1921; Studdiford, Casper, and Scadron, 1938; Hundley, Diehl, and Baggott, 1950). The frequent finding of $N$. gonorrhoeae in the lower genital tract in cases of salpingitis is in striking contrast to the rare finding of gonococci in the fallopian tubes. The fact that gonococci are rarely isolated from the tubes in cases of salpingitis associated with gonorrhoea may depend on the fact that the organisms are relatively short-lived in the

«These ten cases are not included in the present series tubes (Curtis, 1921) or disappear from the lumen of the tubes and are to be found only in the tubal mucosa (Studdiford and others, 1938). In this series sampling was made a few days after the onset of abdominal pain and, with the technique used, tubal specimens included clusters of mucosal cells. Still, the isolation rate of $N$. gonorrhoeae from the tubes was notably low (11.7 per cent. of the salpingitis patients with gonorrhoea).

The frequency of gonorrhoea in the cases of salpingitis seen in this department has remained constant during the last 9 years ( 36 per cent.). In the present series the corresponding figure was 34 per cent., while the incidence in the LGTI group was 8 per cent. The disparity between the salpingitis and LGTI groups may be partly explained by the fact that patients with uncomplicated gonorrhoea are often treated by doctors outside the hospital, whereas patients with salpingitis are referred to the clinic for treatment.

Bacterial cultures from the cervix were of limited value in elucidating the aetiology of acute salpingitis. With the exception of $N$. gonorrhoeae, no other bacterial species was isolated from both the uterine tubes and the lower genital tract.

Trichomonal infestation is commonly seen in patients with salpingitis. $T$. vaginalis was demonstrated by microscopy of wet vaginal smears in $21 \cdot 7$ per cent. of 479 cases of salpingitis seen at this clinic. In the present study the incidence in the salpingitis group was 30 per cent. As in the series of 479 salpingitis cases, no difference was demonstrated in the present series in the occurrence of $T$. vaginalis in gonorrhoeal and non-gonorrhoeal cases. A frequent coincidence of $M$. hominis with $T$. vaginalis has already been noticed (Freundt, 1953). Bercovici, Persky, Rozansky, and Razin (1962) isolated M. hominis twice as often from patients with trichomonal vaginitis as from patients with non-trichomonal vaginitis. In the present study $M$. hominis was recovered with similar frequency in patients with and without trichomoniasis (59 and 65 per cent.).

From one patient in the LGTI group, trichomonads were demonstrated in the cervix and the uterine tubes, which shows that $T$. vaginalis may ascend to the tubes. Trichomonads were not demonstrated in tubal material from cases of salpingitis. An aetiological relationship between $T$. vaginalis and tubal infections has not been established; but as trichomonads may ascend to the adnexa, they might act as carriers of micro-organisms from the lower genital tract to the tubes.

In patients with genital infections, $M$. hominis, Tstrain Mycoplasma, $N$. gonorrhoeae, and $T$. vaginalis seemed to occur independently of one another in the 
lower genital tract. With the exception of $N$. gonorrhoeae, the distribution of these organisms was similar in the salpingitis and the LGTI cases. In the salpingitis group the isolation rates of the organisms were somewhat higher than in the LGTI group, although not to a significant degree. The present study gave no evidence for any difference between the types of lower genital tract infections seen in patients with salpingitis and in those with infections confined to the lower genital tract.

The results of cultures from the uterine tubes suggest that Mycoplasma may play a role in the aetiology of acute salpingitis. In fact, the microorganisms most frequently isolated from the tubes were Mycoplasma. Serological studies have further confirmed an aetiological relationship (Märdh and Weström, to be published).

The high percentage of tubal cultures yielding no growth may indicate that infectious agents other than bacteria and Mycoplasma are involved in the aetiology of salpingitis; in a pilot study of 15 cases, virus isolations were made from tubal material. In two cases, Coxackie B5 and ECHO 6 respectively were isolated from the tubes (unpublished data). This indicates that viruses also may be involved in the aetiology of acute salpingitis.

\section{Summary}

Laparoscopy offers an effective means of obtaining specimens directly from the fallopian tubes in cases of salpingitis.

In fifty patients with acute salpingitis examined by laparoscopy, the occurrence of classic Mycoplasma, T-strain Mycoplasma, gonococci and other bacteria, and $T$. vaginalis in the lower genital tract and the fallopian tubes was studied. In addition, fifty patients with infections confined to the lower genital tract and fifty healthy women were investigated.

$M$. hominis was isolated from the cervix in 62 per cent. of the cases of salpingitis, in 46 per cent. of the cases of infection of the lower genital tract, and in 4 per cent. of the healthy women. $M$. hominis was isolated in pure culture from the fallopian tubes in 12.9 per cent. of the patients with salpingitis who harboured $M$. hominis in the cervix.

No significant difference was demonstrated in the occurrence of T-strain Mycoplasma in women with and without genital infections (50 and 44 per cent. respectively). In two cases of salpingitis, $\mathrm{T}$-strains were recovered from the uterine tubes.

$N$. gonorrhoeae was cultured from the cervix in 34 per cent. of the patients with salpingitis, but from the uterine tubes in only four.
In only three cases were bacteria, apart from $N$. gonorrhoeae, isolated from the fallopian tubes in cases of salpingitis.

$T$. vaginalis was recovered from the uterine tubes from one patient with infection of the lower genital tract, but there were no isolations from any of the patients with salpingitis.

The significance of these findings in the aetiology of acute salpingitis is discussed.

Dr Erik Nordenfelt aided in the virus isolations.

This study was supported by grants from the Alfred Österlunds Stiftelse and from the Kungl. Fysiografiska Sällskapet i Lund.

\section{References}

ARCHER, J. F. (1968) Brit. F. vener. Dis., 44, 232

Bercovici, B., Persky, S., Rozansky, R., and Razin, S. (1962) Amer. F. Obstet. Gynec., 84, 687

BLACK, F. T., and RASMUSSEN, O. G. (1968) Brit. f. vener. Dis., 44, 324

Clyde, W. A. (1964) F. Immunol., 92, 958

Csonka, G. W., Williams, R. E. O., and CoRSE, J. (1966) Lancet, 1, 1292

CurTIS, A. H. (1921) Surg. Gynec. Obstet., 33, 621

Dienes, L., and Edsall, G. (1937) Proc. Soc. exp. Biol. (N.Y.), 36, 740

- Ropes, M. W., SMith, W. E., MAdofF, S., and BAUER, W. (1948) New Engl. F. Med., 238, 509

FREUNDT, E. A. (1953) Acta path. microbiol. scand., 32, 468

Ford, D. K. (1967) Ann. N.Y. Acad. Sci., 143, art. 1, p. 501

and DuVernet, M. (1963) Brit. F. vener. Dis., 39, 18

GotTHARDson, A., and MelÉN, B. (1953) Acta path. microbiol. scand., 33, 291

Gästrin, B., Kalings, L. O., and MarCetic, A. (1968) Ibid., 74, 371

Hayflick, L., and Chanock, R. M. (1965) Bact. Rev. 29, 185

Heynemann, T. (1953) In 'Biologie und Pathologie des Weibes', ed. L. Seitz and A. I. Amreich, 2nd ed., band 5, p. 19. Urban und Schwarzenberg, Berlin

HiRsCH, W. (1952) Bull. Res. Coun. Israel, 2, 207

HuNDLEY, J. M., DIEHL, W. K., and BAGGOTT, J. W. (1950) Amer. F. Obstet. Gynec., 60, 977

JACOBSON, L. (1964) Acta obstet. gynec. scand., 43, 160

and Weström, L. (1969) Amer. F. Obstet. Gynec., 105, 1088

Klieneberger-Nobel, E. (1960) Ann. N.Y. Acad. Sci., 79, art. 10 , p. 615

Lemcke, R., and CsONKA, G. W. (1962) Brit. f. vener. Dis., 38, 212

Melén, B., and Gotthardson, A. (1955) Acta path. microbiol. scand., 37, 196

— and ÖDEBLAD, E. (1951) Scand. F. clin. Lab. Invest., 3,47

Mufson, M. A., Ludwig, W. M., Purcell, R. H., Cate, T. R., Taylor-Robinson, D., and Chanock, R. M. (1965) F. Amer. med. Ass., 192, 1146

Pinkerton, J. H. M. (1963) Practitioner, 190, 309 
Randali, J. H., Stein, R. J., and Ayres, J. (1950) Amer. F. Obstet. Gynec., 59, 404

REYN, A. (1965) Bull. Wld Hlth Org., 32, 449

ShEPARD, M. C. (1967) Ann. N.Y. Acad. Sci., 143, 505

-, AleXander, C. E., Lunceford, C. D., and CAMPBELL, P. E. (1964) F. Amer. med. Ass., 188, 729

and LUNCEFORD, C. D. (1967) f. Bact., 93, 1513

Sjövall, A. (1962) Kungl. fysiogr. Sällsk. Lund Förh., 32, 131

- (1965) 'Proc. I Int. Symp. Gynecological Celioscopy, Palermo (Italy), 1964', p. 329. I.R.E.S., Palermo

STOKES, E. J. (1955) Lancet, 1, 276

StudDiford, W. E., CaSper, W. A., and Scadron, E. N. (1938) Surg. Gynec. Obstet., 67, 176

Cultures à partir de matériel recueilli dans les trompes et le col en cas de salpingite aigüe, avec attention spéciale au Mycoplasma hominis et au mycoplasmes souche $T$.

\section{SOMMAIRE}

La laparoscopie offre un moyen efficace pour obtenir directement des spécimens dans les trompes de Fallope en cas de salpingite.

Chez 50 malades atteintes de salpingite aigüe et examinées par laparoscopie, on a étudié l'occurrence: des mycoplasmes classiques, des mycoplasmes souche $T$., des gonocoques et autres bactéries et du $T$. vaginalis, tant dans les voies génitales basses que dans les trompes de Fallope. En outre, cinquante malades avec des infections limitées aux voies génitales basses, et cinquante femmes saines, furent l'objet d'investigations.

$M$. hominis fut isolé, dans le col, dans 62 pour cent des cas de salpingite, dans 46 pour cent des cas d'infection des voies génitales basses, et dans 4 pour cent chez les femmes saines. $M$. hominis fut isolé en culture pure dans les trompes chez 12,9 pour cent des femmes atteintes de salpingite qui hébergeaient $M$. hominis dans le col utérin.

On ne trouva pas de différence significative dans l'occurrence de la souche $T$. de mycoplasma chez les femmes avec ou sans infection génitale ( 50 et 44 pour cent, respectivement). Dans deux cas de salpingite, des souches $T$. furent obtenues dans les trompes utérines.

$N$. gonorrhoeae fut cultivé dans le col chez 34 pour cent des femmes atteintes de salpingite mais, dans les trompes utérines, seulement dans 4 cas.

A part $N$. gonorrhoeae, on ne trouva des bactéries dans les trompes de Fallope, que dans trois cas de salpingite.

$T$. vaginalis fut retrouvé dans les trompes utérines chez une malade atteinte d'une infection des voies génitales basses, mais il n'en fut isolé dans auncun cas chez les malades atteintes de salpingite.

La signification de ces résultats dans l'étiologie de la salpingite est discutée. 